\title{
Network pharmacology-based and clinically relevant prediction of the active ingredients and potential targets of Chinese herbs in metastatic breast cancer patients
}

\author{
Yu Mao ${ }^{1, *}$, Jian Hao ${ }^{1, *}$, Zi-Qi Jin², Yang-Yang Niu ${ }^{3}$, Xue Yang ${ }^{1}$, Dan Liu ${ }^{1}$, Rui Cao ${ }^{4}$, \\ Xiong-Zhi Wu ${ }^{4}$ \\ ${ }^{1}$ Tianjin Medical University Cancer Institute and Hospital, National Clinical Research Center for Cancer, Key Laboratory of \\ Cancer Prevention and Therapy, Tianjin, 300060, China \\ ${ }^{2}$ Tianjin Medical University, Tianjin, 300070, China \\ ${ }^{3}$ Tianjin Children's Hospital, Tianjin, 300134, China \\ ${ }^{4}$ Zhong-Shan-Men Inpatient Department, Tianjin Medical University Cancer Institute and Hospital, Tianjin, 300060, China \\ *These authors have contributed equally to this study and share first authorship \\ Correspondence to: Xiong-Zhi Wu, email:wuxiongzhi@163.com \\ Keywords: metastatic breast cancer, Chinese herbal medicine, network pharmacology, estrogen receptor, HSP90 \\ Received: October 25, $2016 \quad$ Accepted: January 22, $2017 \quad$ Published: February 15, 2017 \\ Copyright: Mao et al. This is an open-access article distributed under the terms of the Creative Commons Attribution License (CC- \\ BY), which permits unrestricted use, distribution, and reproduction in any medium, provided the original author and source are \\ credited.
}

\section{ABSTRACT}

Chinese Herbal Medicine (CHM) plays a significant role in breast cancer treatment. We conduct the study to ascertain the relative molecular targets of effective Chinese herbs in treating stage IV breast cancer.

Survival benefit of CHM was verified by Kaplan-Meier method and Cox regression analysis. A bivariate correlation analysis was used to find and establish the effect of herbs in complex CHM formulas. A network pharmacological approach was adopted to explore the potential mechanisms of CHM.

Patients in the CHM group had a median survival time of $\mathbf{5 5}$ months, which was longer than the $\mathbf{2 3}$ months of patients in the non-CHM group. Cox regression analysis indicated that CHM was an independent protective factor. Correlation analysis showed that 10 herbs were strongly correlated with favorable survival outcomes $(P<0.01)$. Bioinformatics analyses suggested that the $\mathbf{1 0}$ herbs might achieve anti-breast cancer activity primarily through inhibiting HSP90, ERa and TOP-II related pathways.

\section{INTRODUCTION}

As the most general cancer in female, breast cancer (BC) is the second cause of cancer death among women all over the world, second only to lung cancer. [1-3]. It's estimated that breast cancer account for $15 \%$ of newly diagnosed cancers in Chinese women [4]. The mortality of breast cancer has decreased since the 1990s due to constant efforts in the process of screening, early stage diagnosis and systematic treatment [5]. Metastatic breast cancer (MBC) patients in the late stage of the disease have also benefited a lot from several lines of treatment. The overall survival time of $\mathrm{MBC}$ patients has been improved [6-8]. However, as we can see from a previous study, the 5-year survival rate of patients with MBC was only $24 \%$, and the median survival time has not improved significantly in recent years $[2,8]$.

Chinese Herbal Medicine has been one of the most frequently used alternative treatments for different types of cancer. Both the single Chinese herb and the traditional Chinese herbal formulations have proven to be effective not only in reducing uncomfortable symptoms, such as pain, vomiting, diarrhea, fatigue and leucopenia after surgery and chemotherapy, but also in improving the survival benefits [9-11]. There are also a variety of single Chinese herbs that may be important components in Chinese formulations that have shown anti-proliferative and anti-migration activity in relevant experimental studies [12-15]. However, the specific survival benefits of 
CHM treatment on MBC patients remain unconfirmed and the mechanisms need to be further clarified.

Cancer is a disease in which multiple genes participate in a cumulative and gradual conversion of healthy cells into tumor cells. In addition, it's extremely difficult to analyze the complex compositions in herbal formulas merely through traditional experimental ways. Therefore, network pharmacology, which clarifies the potential mechanisms of complex ingredients through large data set analysis, is a suitable approach to meet this challenge and determine the synergistic effects in cancer treatment that incorporates holistic and systemic views [16, 17]. Thus, we intend to conduct the study in order to explore the potential mechanisms of CHM treatment on MBC using a systematic approach that integrates target prediction and network analysis based on clinical data, just as shown in Figure 1.

\section{RESULTS}

\section{Survival characteristics}

Overall $182 \mathrm{MBC}$ patients were brought into the study. Among that 78 were CHM using patients and 104 under non-CHM treatment. The univariate analysis revealed that ER positive $(P<0.001)$, PR positive $(P<$ $0.001)$, endocrine therapy $(P=0.015)$ and CHM treatment $(P<0.001)$ were protective factors. High blood CA-153 $(P=0.004)$ and CEA $(P=0.001)$ were linked with poorly reduced median overall survival, as shown in Table 1. Shown by the Cox regression analysis results, among the protective factors, CHM was an independent one. The hazard ratio $(\mathrm{HR}=\operatorname{Exp}[\beta])$ of $\mathrm{CHM}$ treatment was 0.591 and the associated $95 \%$ confidence intervals ranged from 0.395 to $0.885(P<0.05)$. The median survival time of CHM group (55 months) was longer than that of the nonCHM group (23 months). The 1-, 3- and 5-year survival rates for the $\mathrm{CHM}$ and non-CHM groups were $96.0 \%$, $69.0 \%, 44.0 \%$, and $72.1 \%, 36.5 \%, 24.7 \%$, respectively $(P<0.001)$. Overall survival curves for CHM and nonCHM groups are shown in Figure 2. The baselines of the patient demographics were equal between patients with and without CHM treatment (Supplementary Table 1). The survival benefits among subgroups in CHM group differed $(P=0.023)$. Patients in Subgroup1 (ER+ and/or PR,+ HER2- ) benefit most from CHM. The median survival time is 67 months. Patients in Subgroup3(ER- and PR -, HER-2+) benefit least. The median survival time is only 38 months (Supplementary Figure 1, Supplementary Table 5).

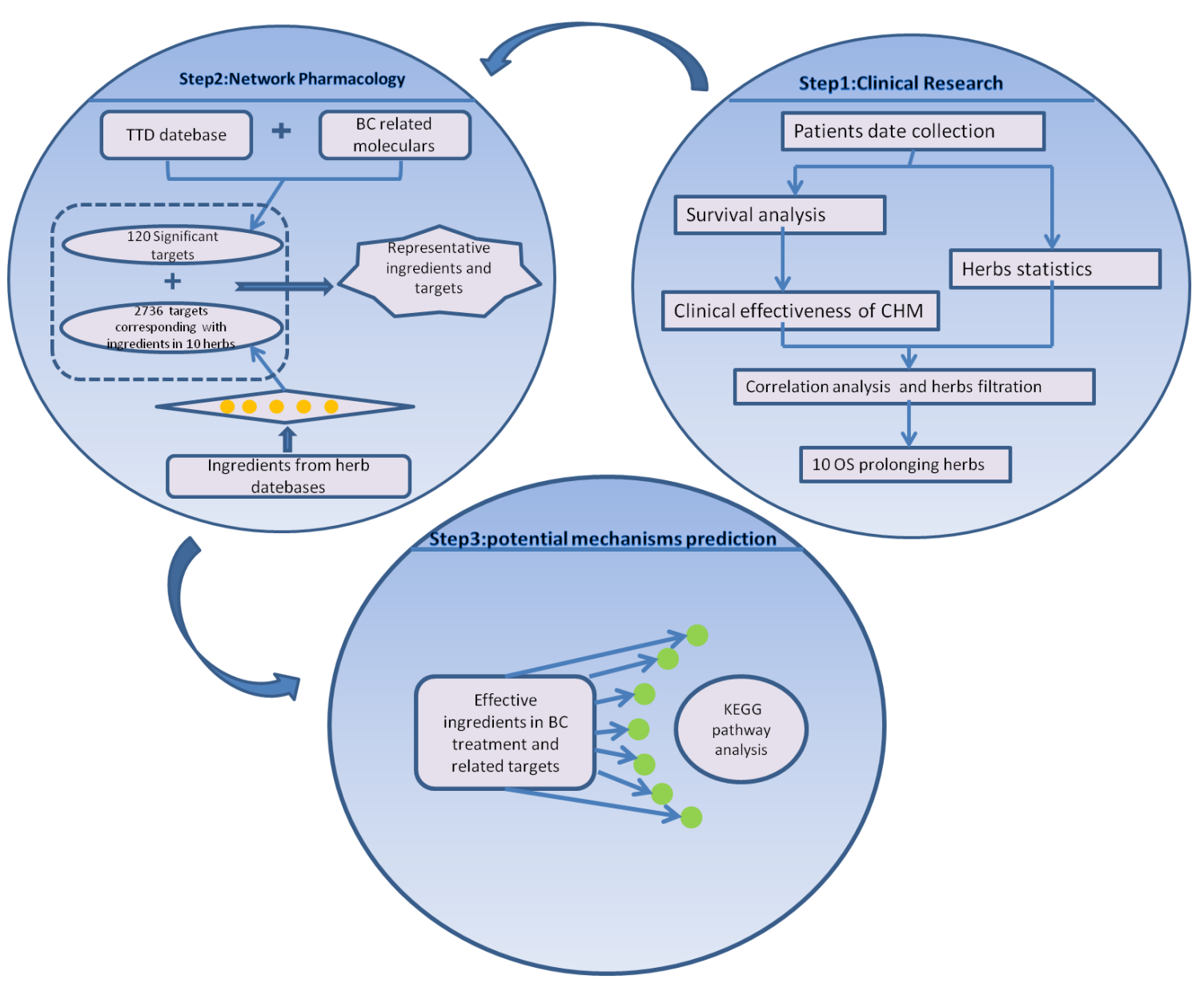

Figure 1: Process overview. 
Table 1: Univariate and multivariate analyses of variables influencing survival of 182 patients with MBC

\begin{tabular}{|c|c|c|c|c|c|c|}
\hline \multirow[b]{2}{*}{ Characteristics } & \multirow[b]{2}{*}{ N (\%) } & \multicolumn{2}{|c|}{ Univariate Analysis } & \multicolumn{2}{|c|}{ Multivariate analysis } & \multirow[b]{2}{*}{$\boldsymbol{P}$} \\
\hline & & $P$ Value & B & $\operatorname{Exp}(\beta)$ & $\begin{array}{c}95 \% \text { CI for } \\
\operatorname{Exp}(\beta)\end{array}$ & \\
\hline Age(year) & & 0.937 & - & - & - & - \\
\hline$<50$ & $57(31.3)$ & & & & & \\
\hline$\geq 50$ & $125(68.7)$ & & & & & \\
\hline Pathological type & & 0.001 & - & - & - & - \\
\hline $\begin{array}{l}\text { Invasive ductal } \\
\text { carcinoma }\end{array}$ & $125(68.7)$ & & & & & \\
\hline others & $57(31.3)$ & & & & & \\
\hline $\begin{array}{l}\text { The first } \\
\text { metastasis place }\end{array}$ & & 0.052 & - & - & - & - \\
\hline Bone & $79(43.4)$ & & & & & \\
\hline non-bone & $103(56.6)$ & & & & & \\
\hline Metastatic style & & 0.113 & - & - & - & - \\
\hline Single-position & $83(45.6)$ & & & & & \\
\hline Muti-position & $99(54.4)$ & & & & & \\
\hline ER & & $<0.001$ & -0.396 & 0.673 & $0.357-1.266$ & 0.673 \\
\hline High & $89(48.9)$ & & & & & \\
\hline Normal & $93(51.1)$ & & & & & \\
\hline PR & & $<0.001$ & -0.272 & 0.788 & $0.455-1.275$ & 0.301 \\
\hline High & $72(39.6)$ & & & & & \\
\hline Normal & $110(60.4)$ & & & & & \\
\hline HER-2 & & 0.083 & - & - & - & - \\
\hline High & $75(41.2)$ & & & & & \\
\hline Normal & $107(58.8)$ & & & & & \\
\hline CA-153 & & 0.004 & 0.444 & 1.559 & $0.965-2.519$ & 0.007 \\
\hline High & $50(27.5)$ & & & & & \\
\hline Normal & $89(48.9)$ & & & & & \\
\hline Missing & $43(23.6)$ & & & & & \\
\hline CEA & & 0.001 & 0.431 & 1.539 & $0.948-2.497$ & 0.081 \\
\hline High & $51(28.0)$ & & & & & \\
\hline Normal & $90(49.5)$ & & & & & \\
\hline Missing & $41(22.5)$ & & & & & \\
\hline Surgery & & 0.764 & - & - & - & - \\
\hline Yes & $165(90.7)$ & & & & & \\
\hline No & $17(9.3)$ & & & & & \\
\hline
\end{tabular}

(Continued) 


\begin{tabular}{|c|c|c|c|c|c|c|}
\hline \multirow[b]{2}{*}{ Characteristics } & \multirow[b]{2}{*}{$\mathbf{N}(\%)$} & \multicolumn{2}{|c|}{ Univariate Analysis } & \multicolumn{2}{|c|}{ Multivariate analysis } & \multirow[b]{2}{*}{$P$} \\
\hline & & $P$ Value & B & $\operatorname{Exp}(\beta)$ & $\begin{array}{l}95 \% \text { CI for } \\
\operatorname{Exp}(\beta)\end{array}$ & \\
\hline $\begin{array}{l}\text { Numbers of } \\
\text { chemotherapy }\end{array}$ & & 0.840 & - & - & - & - \\
\hline $\begin{array}{l}\text { Less than } 3 \\
\text { cycles }\end{array}$ & $22(12.1)$ & & & & & \\
\hline $\begin{array}{l}3 \text { cycles and } \\
\text { more }\end{array}$ & $160(87.9)$ & & & & & \\
\hline Radiotherapy & & 0.729 & - & - & - & - \\
\hline Yes & $123(67.6)$ & & & & & \\
\hline No & $59(32.4)$ & & & & & \\
\hline $\begin{array}{l}\text { Endocrine } \\
\text { theraphy }\end{array}$ & & 0.015 & -0.238 & 1.516 & $0.440-1.412$ & 0.424 \\
\hline Yes & $90(49.5)$ & & & & & \\
\hline No & $92(50.5)$ & & & & & \\
\hline СНM & & $<0.001$ & -0.525 & 0.591 & $0.395-0.885$ & 0.011 \\
\hline Yes & $78(42.9)$ & & & & & \\
\hline No & $104(57.1)$ & & & & & \\
\hline Target theraphy & & 0.552 & & - & - & - \\
\hline Yes & $123(67.6)$ & & - & & & \\
\hline No & $59(32.4)$ & & & & & \\
\hline
\end{tabular}

Abbreviations: CHM: Chinese Herbal Medicine; ER: Estrogen Receptor PR:Progesterone Receptor. CA-153: Carbohydrate Antigen 153 CEA: Carcino-Embryonic Antigen.

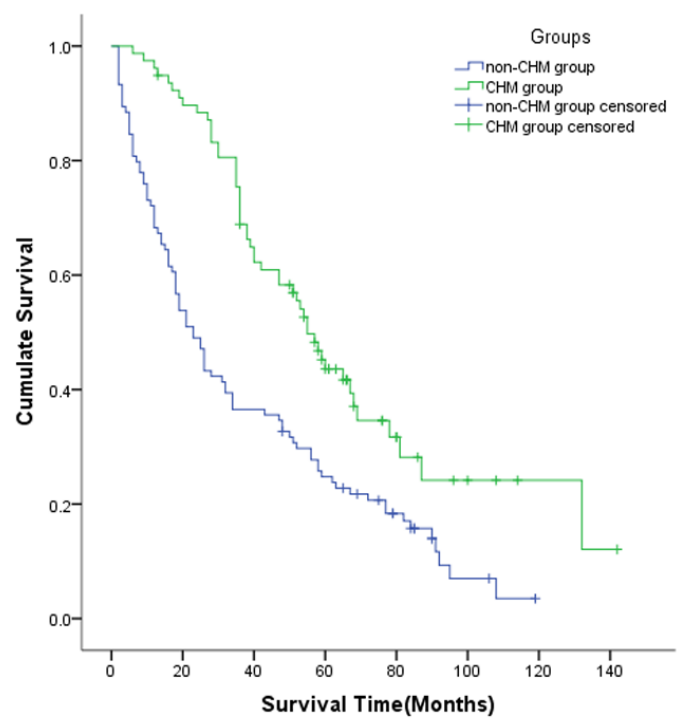

Figure 2: Kaplan-Meier Curve between the CHM and Non-CHM Groups. Patients with CHM treatment had a longer median survival time than those without CHM treatment (55 months VS 23 months, $P<0.001$ ). CHM: Chinese Herbal Medicine. 


\section{Identification of candidate protein targets associated with $\mathrm{BC}$ therapy}

Although there are hundreds of significant genes and proteins that were abnormally expressed in $\mathrm{BC}$ cells, only a small number of them were identified as candidate $\mathrm{BC}$ targets. The Therapeutic Target Database (TTD) is a database for us to get information of therapeutic proteins and nucleic acid targets both known and explored. Therefore, we searched the TTD database and obtained 84 candidate $\mathrm{BC}$ targets. The other 36 candidate targets were from studies that were widely quoted. More detailed information of these $\mathrm{BC}$ targets was listed as Supplementary Table 2. Table 2 shows the online enrichment analysis results.

\section{Candidate herbs associated with breast cancer}

All the Chinese herbal formulas used by the 78 patients were collected; these formulas included a total of 231 types of herbs. Of those 231 herbs, 48 types of herbs, whose frequency of use was more than $10 \%$ of the total frequency of all herbs, were included for correlation analysis. Spearman bivariate correlate analysis showed that 20 herbs positively related to survival time and the correlation coefficient of 10 herbs was $\geqq 0.350(P<0.01)$. The 10 herbs with high correlation coefficients were Cervus Nippon Temminck (NT), Ginger Charcoal (GC), Citri Reticulatae Pericarpium Viride (RP), Phytolaccae Radix (PR), Licorice (Lic), Trichosanthes Kirilowii Maxim (KM), Citri Reticulatae Folium (CR), Panax Notoginseng (PN), Epimedium Herb (EH), Fritillariae Thunbergii Bulbus (FTB).

\section{Target prediction through cI-cT network}

Following the drug target prediction in the TCMSP and TCMID databases, we assembled the druggable proteins as putative targets for composite compounds contained in the 10 herbs (Supplementary Table 3). The potential ingredients predicted in the 10 herbs and their candidate breast cancer-related targets are shown in Supplementary Table 4. A total of 1192 composite ingredients were present in these 10 herbs and 254 of those ingredients have some effect against breast cancer.

In order to show the link between 10 herbs and $\mathrm{BC}$ related targets in an image model, the candidate ingredient-target network (cI-cT) was adopted. In this work, ingredients and targets were represented with nodes and mapped onto interlaced network. As produced in Figure 3, one target in the network may interact with one or more ingredients and vice versa. Thus, the relations between candidate ingredients and $\mathrm{BC}$ targets were vividly displayed. Based on the cI-cT network, the potential ingredients and putative major targets were generated (Table 3). HSP90, ER $\alpha$ and TOP-II were suppressed by multiple ingredients in the 10 herbs. Among this, HSP90 and ER $\alpha$ were suppressed by almost half of the ingredients. So one main anti-BC mechanisms might be HSP90 inhibitory activity. In addition, some proteins involving proliferation and apoptosis processes, such as EGFR, Src, HER2, caspase-3 and Bcl-2, could be hit by more than one ingredient. Inflammatory cytokines like IL-6, IL- $1 \beta$ and TNF- $\alpha$ were also suppressed by multiple ingredients.

Overall, 25 composite ingredients matching the putative breast targets were in high degree distributions. More interestingly, most of the composite ingredients in the 10 herbs were flavonoids. The ingredients with the most potential were common in some of the 10 herbs. For example, beta-sitosterol is a common ingredient shared by Panax Notoginseng (PN), Fritillariae Thunbergii Bulbus (FTB), and Ginger Charcoal (GC). Oleanolic acid is shared by Epimedium herb (EH), Panax Notoginseng (PN), Phytolaccae Radix (PR) and Cervus Nippon Temminck (NT). Palmitic acid is shared by Panax Notoginseng (PN), Trichosanthes Kirilowii Maxim (KM) and Ginger Charcoal (GC). Quercetin is shared by Licorice (Lic), Epimedium herb (EH) and Panax Notoginseng (PN).

\section{Integral mechanisms of anti-BC herbs}

So as to clarify the primary pathways involved in the 10 herbs in $\mathrm{BC}$ treatment, we summarized the canonical pathways that were closely linked with $\mathrm{BC}$ among the potential targets, as shown in Supplementary Table 6. As a result, we identified 64 candidate targets for analysis. The 20 common candidate targets which were shared by more than 10 ingredients are listed in Table 4. HSP90, ER $\alpha$ and TOP-II are the top three targets. The putative targets were mapped to the most relevant pathways (Figure 4).

\section{DISCUSSION}

Approximately 3-10\% of BC cases were discovered to have distant metastasis at the initial diagnosis [32]. Stage IV MBC is still an incurable disease regardless of the progress in multidisciplinary therapy. The principal goal in treating $\mathrm{MBC}$ is to prolong the overall survival as long as possible. The median survival time of MBC is approximately $18-24$ months, which is known from relative breast cancer statistics $[2,6,8,32,33]$. The survival benefits differ in regard to different therapeutic methods based on various molecular subtypes. HER-2+ $\mathrm{MBC}$ patients receiving trastuzumab plus chemotherapy benefited more than patients merely using chemotherapy [34]. For hormone receptor (HR) positive patients receiving endocrine treatment (ET), the benefit seems to be more promising [35]. In this study, the median survival of the control group was 23 months, which is consistent with the above studies. However, the improvement in 
Table 2: Pathways associated with 120 candidate breast cancer targets according to the enrichment analysis based on KEGG and REACT pathway

\begin{tabular}{|c|c|c|c|c|}
\hline Pathway & $\begin{array}{l}\text { Annotated } \\
\text { Targets } \\
\text { Quantity }\end{array}$ & Annotated Genes & $\begin{array}{c}\text { Corrected } \\
P \text {-value }\end{array}$ & Pathway ID \\
\hline $\begin{array}{l}\text { Pathways in } \\
\text { cancer }\end{array}$ & 27 & $\begin{array}{c}\text { AKT1|BAX|BRCA2|CASP3|CASP9|CCND1|CDH1|CD } \\
\text { K4|CDK6|EGFR|HDAC1|IGF1R|MAP2K1|MDM2|MM } \\
\text { P1|MMP2|MMP9|mTOR|NFKB1|PDGFRA|PIK3CG|PI } \\
\text { K3R1|PRKCG|RET|RUNX1|RXRB|TGFB1 }\end{array}$ & $1.22 \mathrm{E}-29$ & KEGG:05200 \\
\hline Cell Cycle & 14 & $\begin{array}{c}\text { BRCA2 } \mid \text { CCND } 1|\mathrm{CCND} 2| \mathrm{CCND} 3|\mathrm{CDC} 25 \mathrm{~A}| \mathrm{CDK} 4 \mid \mathrm{CDK} \\
6|\mathrm{CSNK} 2 \mathrm{~A} 1| \mathrm{DHFR}|\mathrm{HDAC} 1| \mathrm{MDM} 2|\mathrm{TOP} 2 \mathrm{~A}| \mathrm{TUBB} \mid \mathrm{TY} \\
\mathrm{MS}\end{array}$ & $6.97 \mathrm{E}-08$ & REACT:115566 \\
\hline Focal adhesion & 13 & $\begin{array}{l}\text { AKT1|CCND1|CCND2|CCND3|EGFR|IGF1R|MAP2K1| } \\
\text { PDGFRA|PIK3CG|PIK3R1|PRKCG|RARG|SRC }\end{array}$ & $5.61 \mathrm{E}-12$ & KEGG:04510 \\
\hline $\begin{array}{l}\text { ErbB signaling } \\
\text { pathway }\end{array}$ & 11 & $\begin{array}{c}\text { AKT1|CCND1|EGFR|ERBB3|MAP2K1|MTOR|NRG1|P } \\
\text { IK3CG|PIK3R1|PRKCG|SRC }\end{array}$ & $3.26 \mathrm{E}-13$ & KEGG:04012 \\
\hline $\begin{array}{l}\text { MAPK signaling } \\
\text { pathway }\end{array}$ & 10 & $\begin{array}{c}\text { AKT1|CASP3|EGFR|HSPB1|MAP2K1|NFKB1|PDGFR } \\
\text { A|PRKCG|TGFB1|TNF }\end{array}$ & $1.18 \mathrm{E}-06$ & KEGG:04010 \\
\hline $\begin{array}{l}\text { p53 signaling } \\
\text { pathway }\end{array}$ & 9 & $\begin{array}{c}\text { BAX } \mid \text { CASP3 } \mid \text { CASP9 } \mid \text { CCND1 } \mid \text { CCND2 } \mid \text { CCND3 } \mid \text { CDK4 } \mid \mathrm{C} \\
\text { DK6 } \mid \text { MDM2 }\end{array}$ & $4.81 \mathrm{E}-11$ & KEGG:04115 \\
\hline Endocytosis & 9 & $\begin{array}{c}\text { EGFR } \mid \text { ERBB3|IGF1R } \mid \text { MDM2|PDGFRA } \mid \text { RAB7A } \mid \text { RET } \mid S \\
\text { RC } \mid \text { TGFB1 }\end{array}$ & $1.18 \mathrm{E}-08$ & KEGG:04144 \\
\hline $\begin{array}{l}\text { Cytokine- } \\
\text { cytokine receptor } \\
\text { interaction }\end{array}$ & 9 & $\begin{array}{c}\text { CCL2|CCL5|CXCL1|EGFR|PDGFRA } \mid \text { PRL } \mid \text { PRLR } \mid \text { TGF } \\
\text { B1|TNF }\end{array}$ & $9.18 \mathrm{E}-08$ & KEGG:04060 \\
\hline $\begin{array}{l}\text { VEGF signaling } \\
\text { pathway }\end{array}$ & 8 & $\begin{array}{c}\text { AKT1|CASP9|HSPB1|MAP2K1|PIK3CG|PIK3R1|PRK } \\
\text { CG|SRC }\end{array}$ & $7.71 \mathrm{E}-11$ & KEGG:04370 \\
\hline Apoptosis & 8 & $\begin{array}{c}\text { AKT1|BAX|CASP3|CASP9|NFKB1|PIK3CG|PIK3R1|T } \\
\text { NF }\end{array}$ & $1.66 \mathrm{E}-10$ & KEGG:04210 \\
\hline $\begin{array}{l}\text { Jak-STAT } \\
\text { signaling pathway }\end{array}$ & 8 & $\begin{array}{c}\text { AKT1 } \mid \text { CCND } 1|\mathrm{CCND} 2| \mathrm{CCND} 3|\mathrm{PIK} 3 \mathrm{CG}| \mathrm{PIK} 3 \mathrm{R} 1|\mathrm{PRL}| \\
\text { PRLR }\end{array}$ & $1.54 \mathrm{E}-08$ & KEGG:04630 \\
\hline $\begin{array}{l}\text { Chemokine } \\
\text { signaling pathway }\end{array}$ & 8 & $\begin{array}{c}\text { AKT1|CCL2 } \mid \text { CCL5 } \mid \text { CXCL1|MAP2K1|NFKB1 } \mid \text { PIK3CG } \mid \\
\text { PIK3R1 }\end{array}$ & 7.63E-08 & KEGG:04062 \\
\hline $\begin{array}{l}\text { Toll-like receptor } \\
\text { signaling pathway }\end{array}$ & 7 & AKT1|CCL5|MAP2K1|NFKB1|PIK3CG|PIK3R1|TNF & $2.56 \mathrm{E}-08$ & KEGG:04620 \\
\hline $\begin{array}{l}\text { Steroid hormone } \\
\text { biosynthesis }\end{array}$ & 6 & AKR1C1|CYP19A1|CYP1B1|HSD17B1|STS|SULT1E1 & $1.48 \mathrm{E}-08$ & KEGG:00140 \\
\hline Gap junction & 6 & EGFR|MAP2K1|PDGFRA|PRKCG|SRC|TUBB & $3.10 \mathrm{E}-07$ & KEGG:04540 \\
\hline Tight junction & 6 & AKT1|CDK4|CDK6|CSNK2A1|PRKCG|SRC & 3.09E-06 & KEGG:04530 \\
\hline $\begin{array}{l}\text { Natural killer } \\
\text { cell mediated } \\
\text { cytotoxicity }\end{array}$ & 6 & CASP3|MAP2K1|PIK3CG|PIK3R1|PRKCG|TNF & $3.48 \mathrm{E}-06$ & KEGG:04650 \\
\hline $\begin{array}{l}\text { Regulation of } \\
\text { actin cytoskeleton }\end{array}$ & 6 & EGFR|MAP2K1|PDGFRA|PIK3CG|PIK3R1|RARG & 4.01E-05 & KEGG:04810 \\
\hline $\begin{array}{l}\text { NOD-like } \\
\text { receptor signaling } \\
\text { pathway }\end{array}$ & 5 & CCL2|CCL5|CXCL1|NFKB1|TNF & 8.77E-07 & KEGG:04621 \\
\hline
\end{tabular}

(Continued) 


\begin{tabular}{lcccc}
\hline Pathway & $\begin{array}{c}\text { Annotated } \\
\text { Targets } \\
\text { Quantity }\end{array}$ & Annotated Genes & $\begin{array}{c}\text { Corrected } \\
\boldsymbol{P} \text {-value }\end{array}$ & Pathway ID \\
\hline $\begin{array}{l}\text { Adherens junction } \\
\text { GnRH signaling } \\
\text { pathway }\end{array}$ & 5 & CDH1|CSNK2A1|EGFR|IGF1R|SRC & $2.76 \mathrm{E}-06$ & KEGG:04520 \\
$\begin{array}{l}\text { Cell-Cell } \\
\text { communication }\end{array}$ & 5 & EGFR|MAP2K1|MMP2|MMP9|SRC & $1.49 \mathrm{E}-05$ & KEGG:04912 \\
$\begin{array}{l}\text { Insulin signaling } \\
\text { pathway } \\
\text { mTOR signaling } \\
\text { pathway }\end{array}$ & 5 & CDH1|CDH2|KRT5|PIK3R1|SRC & $4.44 \mathrm{E}-05$ & REACT:111155 \\
\hline
\end{tabular}

overall survival is still limited. We indeed have not seen as many benefits as we expected in MBC, especially in adjuvant chemotherapy [36].

CHM is a significant and frequently used adjuvant therapy in China. The advantages of CHM in treating breast cancer are not only the effects in relieving uncomfortable symptoms such as pain, vomiting, leucopenia, and weakness but also in survival benefits $[9,10,37]$. Studies have shown encouraging results for breast cancer therapy $[9,38]$. Our study has also revealed gratifying survival outcomes with an obvious improved median survival time of 55 months. Although the effects of CHM in breast cancer treatment have been explored in several clinical studies, the mechanisms in depth are not clear.
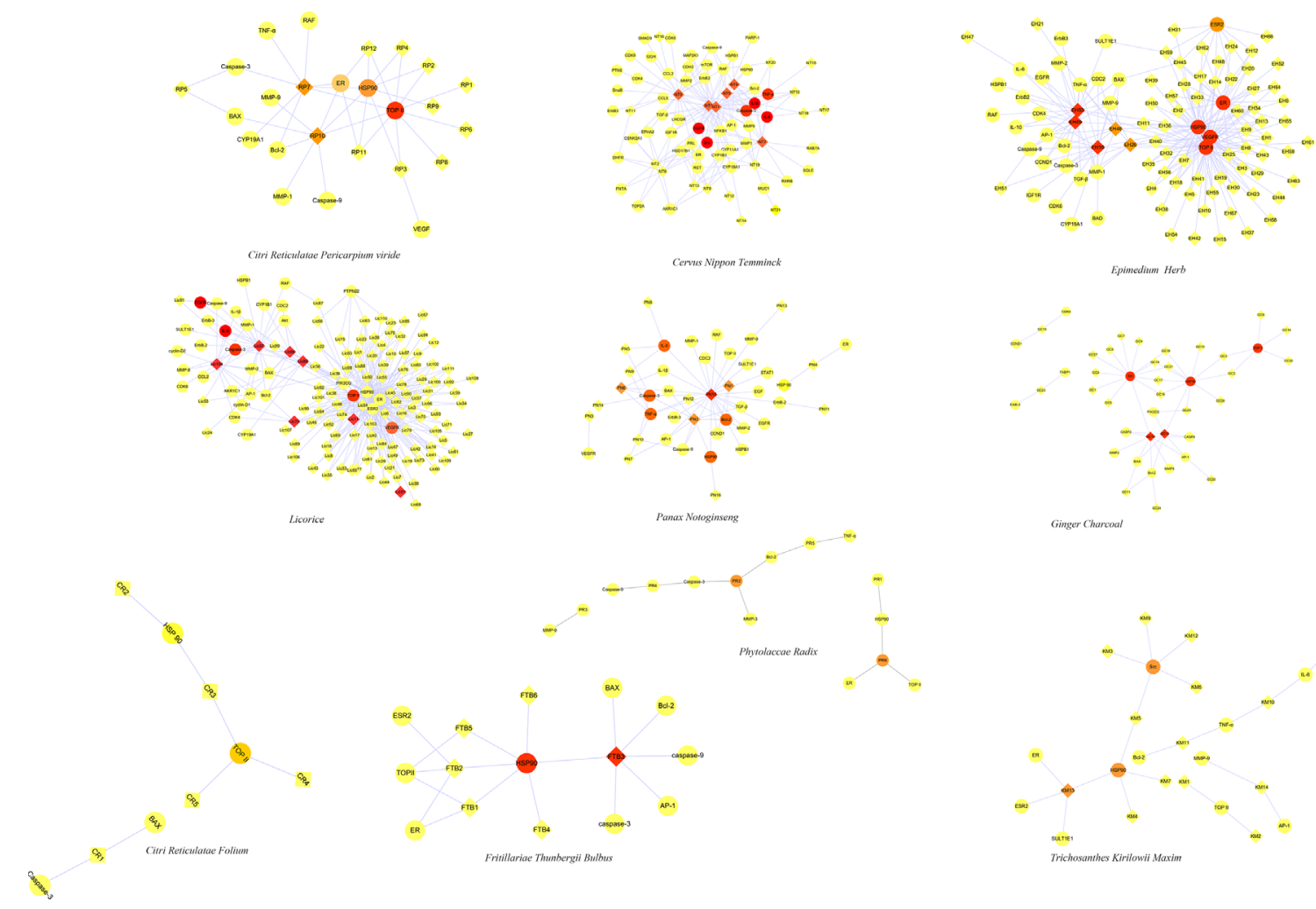

Figure 3: The Ingredient-target Networks. The diamond nodes represent ingredients; the circular nodes represent targets; and the colors of the nodes are illustrated from red to yellow in descending order of degree values. (NT, Cervus Nippon Temminck; GC, Ginger Charcoal; RP, Citri Reticulatae Pericarpium Viride; PR, Phytolaccae Radix; Lic, Licorice; KM, Trichosanthes Kirilowii Maxim; CR, Citri Reticulatae Folium; PN, Panax Notoginseng; EH, Epimedium Herb; FTB, Fritillariae Thunbergii Bulbus). 
Table 3: The major ingredients and major targets of 10 herbs

\begin{tabular}{|c|c|c|c|c|c|c|c|}
\hline $\begin{array}{l}\text { Chinese } \\
\text { Name }\end{array}$ & Latin name & $\begin{array}{c}\text { NO. of } \\
\text { ingredients }\end{array}$ & Major ingredients & $\begin{array}{l}\text { Number } \\
\text { of targets }\end{array}$ & $\begin{array}{l}\text { Major } \\
\text { targets }\end{array}$ & $\begin{array}{c}\text { Correlation } \\
\text { coefficient }\end{array}$ & $\begin{array}{c}P \text { - } \\
\text { value }\end{array}$ \\
\hline 醋青皮 & $\begin{array}{l}\text { Citri } \\
\text { Reticulatae } \\
\text { Pericarpium } \\
\text { viride }\end{array}$ & 12 & $\begin{array}{l}\text { Naringenin (RP-07) } \\
\text { Nobiletin (RP-10) }\end{array}$ & 13 & $\begin{array}{c}\text { TOPII } \\
\text { HSP90 } \\
\text { ER }\end{array}$ & 0.471 & $<0.001$ \\
\hline 醋商陆 & $\begin{array}{c}\text { Phytolaccae } \\
\text { Radix }\end{array}$ & 6 & $\begin{array}{c}\text { Esculetin (PR-02) } \\
\text { Xanthomicrol (PR-06) }\end{array}$ & 9 & $\begin{array}{c}\text { HSP90 } \\
\text { Caspase-3 }\end{array}$ & 0.433 & $<0.001$ \\
\hline 鹿角霜 & $\begin{array}{c}\text { Cervus } \\
\text { Nippon } \\
\text { Temminck }\end{array}$ & 20 & $\begin{array}{l}\text { beta-estradiol (NT-1) } \\
\text { Adenosine triphosphate } \\
\text { (NT-3) } \\
\text { alpha-estradiol (NT-4) } \\
\text { Ceramide (NT-5) } \\
\text { Cerebroside (NT-6) }\end{array}$ & 50 & $\begin{array}{l}\text { Caspase-3 } \\
\text { EGFR } \\
\text { IL1 } \beta \\
\text { IL-6 } \\
\text { Src } \\
\text { TNF- } \alpha\end{array}$ & 0.396 & 0.001 \\
\hline 橘叶 & $\begin{array}{c}\text { Citri } \\
\text { Reticulatae } \\
\text { Folium }\end{array}$ & 5 & Hesperidin (CR-1) & 4 & $\begin{array}{c}\text { HSP90 } \\
\text { TOPII }\end{array}$ & 0.395 & 0.001 \\
\hline 瓜蒌 & $\begin{array}{c}\text { Trichosanthes } \\
\text { Kirilowii } \\
\text { Maxim }\end{array}$ & 14 & Tricin (KM-13) & 11 & $\begin{array}{l}\text { HSP90 } \\
\text { Src }\end{array}$ & 0.394 & 0.002 \\
\hline 姜炭 & $\begin{array}{c}\text { Ginger } \\
\text { Charcoal }\end{array}$ & 27 & $\begin{array}{l}\text { 6-gingerol (GC-10) } \\
\text { beta-sitosterol (GC-12) }\end{array}$ & 14 & $\begin{array}{c}\text { HSP90 } \\
\text { ER } \\
\text { TOPII }\end{array}$ & 0.376 & 0.003 \\
\hline 浙贝母 & $\begin{array}{c}\text { Fritillariae } \\
\text { Thunbergii } \\
\text { Bulbus }\end{array}$ & 6 & beta-sitosterol(FTB-03) & 9 & $\begin{array}{l}\text { HSP90 } \\
\text { TOPII }\end{array}$ & 0.375 & 0.002 \\
\hline 淫羊蕉 & $\begin{array}{l}\text { Epimedium } \\
\text { Herb }\end{array}$ & 68 & $\begin{array}{c}\text { Apigenin (EH-16) } \\
\text { Emodin(EH-26) } \\
\text { Kaempferol (EH-46) } \\
\text { Luteolin (EH-49) } \\
\text { Quercetin (EH-53) } \\
\text { Anhydroicaritin (EH-14) } \\
\text { Artonin U (EH-17) }\end{array}$ & 30 & $\begin{array}{l}\text { HSP90 } \\
\text { TOPII } \\
\text { ESR2 } \\
\text { ER } \\
\text { VEGFR } \\
\text { Caspase } 3 \\
\text { MMP-1 } \\
\text { TNF- } \alpha\end{array}$ & 0.370 & 0.003 \\
\hline 三七 & $\begin{array}{c}\text { Panax } \\
\text { Notoginseng }\end{array}$ & 16 & $\begin{array}{c}\text { Quercetin (PN-15) } \\
\text { beta-sitosterol(PN-02) } \\
\text { Ginsenoside rh2 (PN-06) } \\
\text { beta-elemene (PN-01) }\end{array}$ & 27 & $\begin{array}{l}\text { Caspase-3 } \\
\text { HSP90 } \\
\text { IL-6 } \\
\text { TNF- } \alpha \\
\text { Bcl-2 }\end{array}$ & 0.358 & 0.004 \\
\hline 甘草 & Licorice & 110 & $\begin{array}{l}\text { Ursolic acid (Lic-104) } \\
\text { Quercetin (Lic-97) } \\
\text { Naringenin (Lic-86) } \\
\text { licochalcone a (Lic-72) } \\
\text { Kaempferol (Lic-66) } \\
\text { Gancaonin A/B/G/H } \\
\text { 1-Methoxyphaseollidin } \\
\text { (Lic-11) }\end{array}$ & 33 & $\begin{array}{c}\text { HSP90 } \\
\text { TOPII } \\
\text { ESR2 } \\
\text { ER } \\
\text { VEGFR } \\
\text { Caspase } 3 \\
\text { Bcl-2 }\end{array}$ & 0.352 & 0.005 \\
\hline
\end{tabular}


Table 4: Putative targets for main ingredients present in 10 Herbs

\begin{tabular}{|c|c|c|}
\hline Putative Targets & $\begin{array}{l}\text { NO. Of } \\
\text { Ingredients }\end{array}$ & The Top Drugs (NO. Of Ingredients) \\
\hline HSP90 & 171 & Licorice(Lic, 78), Epimedium Herb(EH,50) \\
\hline ER & 142 & Licorice(Lic, 89),Epimedium Herb(EH,25), Ginger Charcoal $(G C, 13)$ \\
\hline TOPII & 123 & $\begin{array}{c}\text { Epimedium Herb(EH,52),Licorice(Lic,40), Citri Reticulatae Pericarpium } \\
\text { viride }(R P, 10)\end{array}$ \\
\hline VEGFR2 & 57 & Licorice(Lic, 24),Epimedium Herb(EH,9), Radix Achyranthis Bidentatae(AB,2) \\
\hline Caspase-3 & 36 & Epimedium Herb(EH,32),Licorice(Lic,24), \\
\hline AP-1 & 30 & Licorice(Lic,9),Epimedium Herb(EH,8),Cervus Nippon Temminck(NT, 6) \\
\hline Bcl-2 & 28 & Licorice(Lic,5), Panax notoginseng $(P N, 4)$ \\
\hline TNF- $\alpha$ & 26 & $\begin{array}{c}\text { Cervus Nippon Temminck(NT, 8),Epimedium Herb(EH,6),Panax } \\
\text { notoginseng }(P N, 5)\end{array}$ \\
\hline PIK3CG & 20 & Licorice(Lic, 18), Ginger Charcoal $(G C, 2)$ \\
\hline BAX & 19 & Licorice(Lic,4),Epimedium Herb(EH,4), Ginger Charcoal $(G C, 3)$ \\
\hline IL-6 & 19 & Licorice(Lic,4), Panax notoginseng(PN,4),Cervus Nippon,Temminck (NT,7) \\
\hline Caspase-9 & 18 & Panax notoginseng(PN,4),Licorice(Lic,3), Epimedium Herb(EH,3) \\
\hline MMP-9 & 17 & Cervus Nippon Temminck(NT,5),Epimedium Herb(EH,4) \\
\hline IL-1 $\beta$ & 13 & Cervus Nippon Temminck(NT,8),Licorice(Lic,3) \\
\hline EGFR & 13 & Cervus Nippon Temminck(NT,8) \\
\hline Src & 13 & Cervus Nippon Temminck (NT,8),Trichosanthes Kirilowii Maxim $(K M, 3)$ \\
\hline MMP-1 & 12 & Epimedium Herb(EH,5), Licorice(Lic,3) \\
\hline MMP-2 & 11 & Licorice(Lic,3), Epimedium Herb(EH,2), \\
\hline CCND1 & 10 & Epimedium Herb(EH,3), Licorice(Lic,3), \\
\hline ErbB2 & 10 & Cervus Nippon Temminck (NT,3), Licorice(Lic,2), Panax notoginseng(PN,2) \\
\hline
\end{tabular}

In our study, a total of 120 candidate targets in BC were obtained from the TTD database and the literature. The results of online enrichment analysis showed that these candidate $\mathrm{BC}$ targets were mostly belonged to intracellular signaling cascades in tumor growth and metastasis, such as the p53, ErbB, MAPK and VEGF signaling pathway (Supplementary Table 7).

The clinical findings demonstrated that 10 herbs were significantly associated with the survival benefits of MBC patients. A total of 1192 composite ingredients were present in these 10 herbs and 254 ingredients that have some effect against breast cancer were retained for further research. Among the 254 chemical components, 26 had a high degree of distribution and each of them hit the putative targets. Interestingly, most of the composite ingredients in the 10 herbs were flavonoids. Flavonoids have a wide range of properties and diverse biological effects. Numerous studies have reported interesting pre-clinical activity of flavonoids in kinds of cancers, suggesting their possible use in cancer prevention and treatment especially in BC [39-41]. Thus, it is of importance to probe the potential of these compounds in cancer treatments.

The ingredient-target herb networks showed that Chinese herbs played a role in treating BC through a biological network model. We identified major high-degree distribution ingredients in the 10 herbs. Our data showed that quercetin and kaempferol were shared by most of the 10 herbs and might play a major role in $\mathrm{BC}$ treatment.

Quercetin, a kind of flavonoids found in various plants, can inhibit the proliferation of a broad scope of malignancies [42-46]. It's also an ingredient in all of the 10 herbs. In $\mathrm{BC}$ cell lines, researches have reported that quercetin decreased the number of viable cells through increasing the level of apoptosis promoting protein Bax and decreasing the level the of Bcl-2 that inhibits cell apoptosis $[47,48]$. The anti-tumor activity of kaempferol has been verified in BC. One study shows that kaempferol treatment arrest cell cycle in G2/M-phase and induces cell apoptosis [49]. Interestingly, quercetin and kaempferol are 
the main components of major flavonols in herbs and plant food and both also have antioxidant capacity [50].

As shown in Table 4, Licorice and Epimedium Herb played principal roles in the treatment of BC. Licorice is a kind of classic Chinese herb. It's commonly used in numerous formulas. Licorice contains various kinds of ingredients such as polysaccharides, triterpenoids and polyphenols. Studies have proved its pharmaceutical functions including anti-tumor effect. Glycyrrhizic acid can inhibit cyclooxygenase and lipoxygenase; suppress protein kinase $\mathrm{C}$; reduce the expression of epidermal growth factor receptor (VEGFR). What's more, Licorice polyphenols has the effect of inducing apoptosis. [51, 52].

Epimedium Herb (EH) is a widely used Chinese medicine in numbers of formulas in treating bone diseases. Studies have shown that flavonoids of EH could reduce the bone loss [53]. Further studies proved that flavonoids in EH perform osteoblastic functions by stimulating ER. [54, 55]. The anti-cancer function of $\mathrm{EH}$ had not been widely reported, but the osteoblastic functions are rather attractive in treating $\mathrm{BC}$ bone metastases.

Among 64 major putative targets of the 10 herbs on BC therapy, HSP90, ER $\alpha$ and TOP-II are most directly depressed by these herbs. For BC therapies, the ER highly expressing in almost $70 \%$ of all breast tumors [56] is considered a molecule to target. As a member of the steroid receptor superfamily, ER $\alpha$ could promote various target cells to proliferate and differentiate. However, in the majority of breast cancers, ER $\alpha$ was greatly upregulated compared to normal breast cells and its expression was a hallmark of hormone-dependent tumor growth [57]. What's more, ER $\alpha$ play a significant role in $\mathrm{BC}$ initiation besides progression for benign breast epithelium with high $\mathrm{ER} \alpha$ levels were more likely to become malignant ones [58]. Researchers have found that flavonoids can bind both isoforms of the ER, primarily as agonists competing with E2 [59], and induce biological responses traditionally associated with the binding of the natural hormone in a dose-dependent manner $[60,61]$. As most of the chemical components with a high degree of distribution in the 10 herbs are flavonoids, it was not surprising that ER $\alpha$ was one of the putative targets.

HSP90 is a common kind of heat shock protein. It's of great help in maintaining the function of numerous intracellular proteins involving the process of apoptosis and cell cycle. [62]. When it comes to the BC cells, HSP90 plays an important role in keeping the stability of $\mathrm{BC}$ related proto-oncogenes such as estrogen receptor (ER), progesterone receptor (PR), Her2/neu and relative downstream proteins [63]. Over-expressed HSP90 was

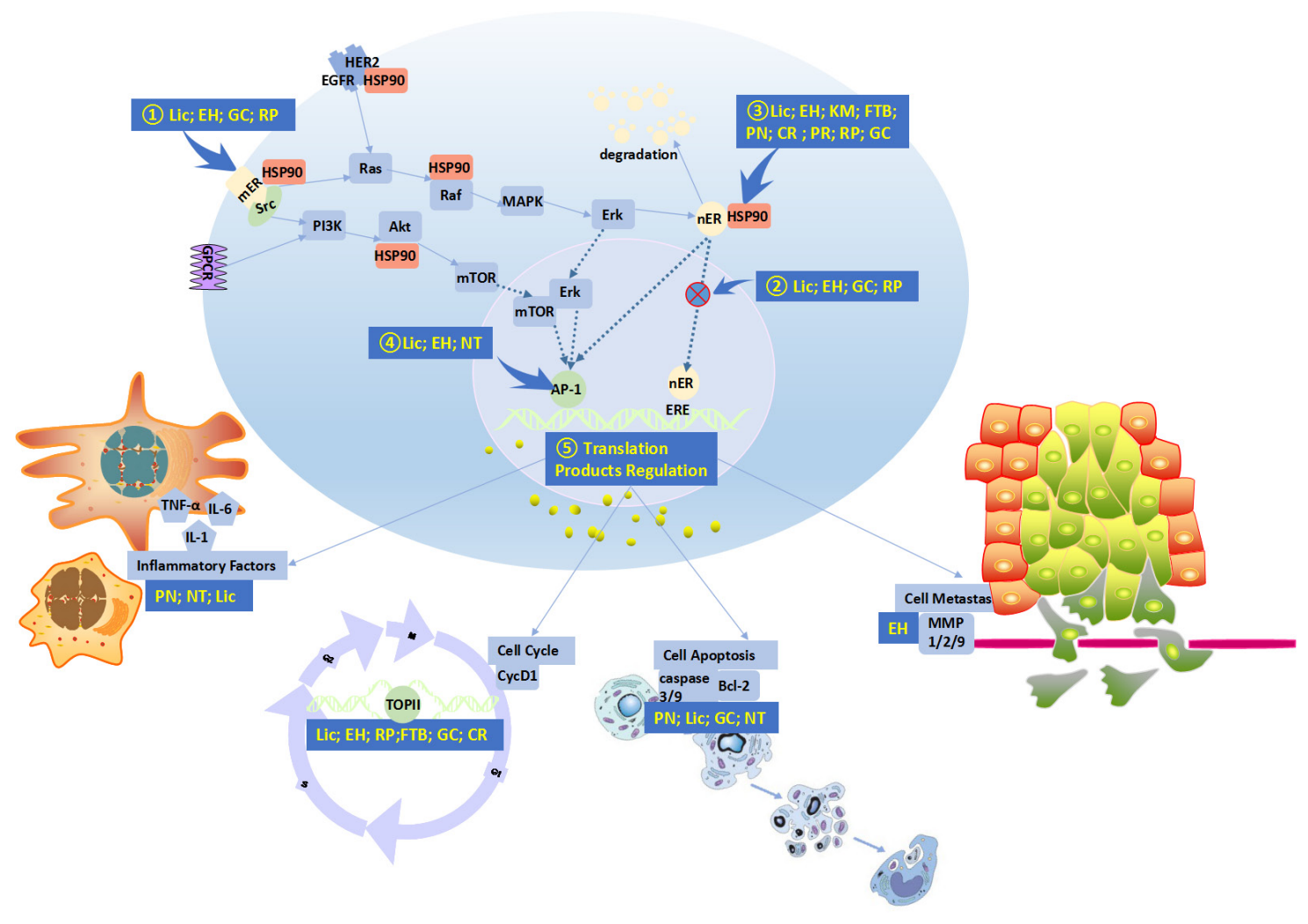

Figure 4: Associated pathways of the 10 Herbs Against Breast Cancer. The 10 herbs might achieve anti-breast cancer activity primarily through the following routes: 1) Blockade of estrogen action via ER (estrogen receptor) antagonism. 2) Blocking the nuclear translocation of the ER. 3) Leading to degradation of the ER and oncoproteins through dissociation from HSP90. 4) Blocking transcriptional activity of AP-1 and ER. 5) Regulating the function of translation products by AP-1 and ER. 
linked with bad prognosis in $\mathrm{BC}$ [64], indicating that HSP90 might be an effective target. The suppression of HSP90 may accelerate degradation of ER, PR, AKT, c-SRC, and RAF proteins.

Topoisomerase II alpha (TOP2A) is an important enzyme in the process of DNA replication. It has already become the target of some anticancer drugs. TOP2A is closely linked with the ERB2/HER-2/neu oncogene in the process of amplification. [65-66]. It would be interesting to explore the anti-cancer effect of the 10 herbs through DNA topoisomerase II-alpha-dependent cellular cytotoxicity.

In the present study, cancer-related targets involved in different stages of oncogenesis were included in the targets, determined through a network analysis, of 10 herbs. To better understand the functions of the targets associated with these 10 herbs, we analyzed the related pathways. As discussed before, most of the composite ingredients in the 10 herbs were flavonoids, and evidence supported the potential of these compounds to target different pathways and mechanisms underlying the complexity of cancer. These properties seem to be largely linked to their relatively simple structure: the presence of conjugated electron systems and aromatic rings make them stable and reactive; whereas, their overall structure allows them to act as substrates, inhibitors or agonists for numerous enzymes or molecules in cancer development and progression. Because of the important role of the ER in $\mathrm{BC}$ development, inhibition of the ER by flavonoids may be the most important mechanism in BC treatment. Therefore, by summarizing the canonical pathways that are highly correlated with $\mathrm{BC}$ and that are among the potential targets, the 10 herbs might achieve anti-breast cancer activity primarily through the following routes: 1) blockade of estrogen action via ER (estrogen receptor) antagonism; 2) blocking the nuclear translocation of the ER; 3) leading to degradation of the ER and oncoproteins through dissociation from HSP90; 4) blocking the transcriptional activity of AP-1 and the ER; 5) regulating the function of translation products by AP-1 and the ER.

Although network pharmacology is a promising method for identifying potential targets and active ingredients, there are some drawbacks that affect the analysis results. (i) The ingredients of the herbs were screened based on DL values, which might be inconsistent with the precise ingredients; (ii) the validated targets of these ingredients might be influenced by highly related studies; and (iii) the accuracy of target prediction depends on the target prediction tools.

\section{MATERIALS AND METHODS}

\section{Patient characteristics}

Patients with metastatic breast cancer between June 2004 and December 2011 in Tianjin Medical University
Cancer Hospital were retrospectively studied. Information about the patients was collected from inpatient and outpatient medical records in Tianjin Medical University Cancer Hospital or from direct patient follow-up visits. After analysis of the data gathered and telephone follow ups, a total of 182 patients with $\mathrm{MBC}$ were available for this study.

The following is major inclusion criteria: aged over 18; at least one metastatic organ diagnosed by biopsy specimen obtained from puncture or imageological diagnosis at the first hospital visit or developed metastasis after therapy; received chemotherapy no less than three times; and patients in the CHM group received CHM treatment $\geqq 4$ weeks. Major exclusion criteria included the following: men; serious complications (liver failure, respiratory failure, severe mental disorder, severe cardiac diseases, etc.) concurrent cancer; incomplete medical records; without exact metastatic time; and failed to follow up.

\section{Treatment}

MBC patients in the non-CHM group had accepted conventional western medicine (WM), including chemotherapy, radiotherapy and targeted therapy. Most of the ER positive patients also received endocrine therapy. All the patients in non-CHM group have never received any traditional Chinese medicine during and after hospitalization.

For the CHM group, the patients were treated by TCM formulas according to the different syndrome types in addition to conventional WM. In general, the formulas used in the present study contained 20-30 types of Chinese herbal substances. The patient formulas were collected every 2 weeks, because the formulas were modulated judged from symptoms changes in each 2 weeks. The formula collection work was started from the first CHM treatment time to the date the patients died or the time of data closure. At the end of the follow-up process, the CHM formulas of the 78 patients in the CHM group were gathered for us to analyze. The MBC patients had received CHM treatment for 22896 days altogether. To clearly distinguish the commonly used herbs, the single herb frequency/total frequency was used. The herbs with frequency $>10 \%$ (single frequency/total frequency) were used to make bivariate correlation analysis. Herbs with correlation coefficient $\geqq 0.350(P<0.01)$ were included for further network pharmacology dissection. Herbs with frequency $<10 \%$ were not commonly used, and the use of which was to relieve various uncomfortable symptoms and they were changed after a 14-day interval.

\section{Candidate BC-related targets}

Candidate $\mathrm{BC}$ targets were obtained from two existing resources: (1) Therapeutic Target Database [18] 
(http://bidd.nus.edu.sg/group/cjttd/ttd_home.asp, Version 4.3.02 release on Sep 15th, 2013). Therapeutic protein targets, both known and explored, were used as BC targets. Totally, we got 84 candidate $\mathrm{BC}$-related targets in the database. (2) Literature, a total of $36 \mathrm{BC}$ targets were from studies that are widely quoted [19-21]. Pathway enrichment analysis for candidate $\mathrm{BC}$ targets were performed online using the genes of candidate $\mathrm{BC}$ targets [22] (http://ctdbase.org/tools/analyzer.go).

\section{Herb formulation ingredient collection and target fishing}

As in our previous study [23], the chemical ingredients were collected from the Traditional Chinese Medicine Systems Pharmacology (TCMSP) Database [24] (http://sp.nwu.edu.cn/), and Traditional Chinese Medicine Integrative (TCMID) Database (http://www.megabionet. org/tcmid/) [25] and subsequently screened according to drug-likeness (DL) values, considering both pharmacodynamic and pharmaco-kinetic properties. The ingredients with a DL value higher than 0.18 were retained for further investigation.

Target fishing was conducted to confirm or predict the potential targets of the chemical ingredients. The validated targets were extracted from the Herbal Ingredients' Targets (HIT) Database [26] (http://lifecenter. sgst.cn/hit/). The predicted targets were obtained using ChemMapper [27] (http://lilab.ecust.edu.cn/ chemmapper/), an online tool for predicting targets based on 3D similarity.

\section{Network construction and analysis}

Ten herbs (Cervus Nippon Temminck (NT), Ginger Charcoal (GC), Citri Reticulatae Pericarpium Viride (RP), Phytolaccae Radix (PR), Licorice (Lic), Trichosanthes Kirilowii Maxim (KM), Citri Reticulatae Folium (CR), Panax Notoginseng (PN), Epimedium Herb (EH), Fritillariae Thunbergii Bulbus (FTB)) were found to have high correlation coefficients. The ingredientstargets networks were constructed for these herbs using Cytoscape software [28] (Version 3.2.1). The network was analyzed using Cytoscape software with the CentiScaPe plugin [29] to calculate topological parameters, including the degree, betweenness, closeness and centroid. The significant nodes representing putative major ingredients and major targets of herbs were explored.

\section{Ethics approval and consent to participate}

This study was performed with the approval of the Ethics Committee of Tianjin Medical University. Exemption from obtaining informed consent was approved through the Ethics Committee as this study was retrospective and many patients had died prior to conducting the study. This study conformed to the standards of the Declaration of Helsinki. The informed consent was not required because personal identifying information was not involved.

\section{Statistical analysis}

Overall survival was defined as the time from the day MBC was diagnosed to the day the patient died of breast cancer or the last day the patient was followed. Baseline comparison was analyzed by the $\chi^{2}$ test. KaplanMeier curves and Multivariate Cox regression analysis were used to evaluate the differences in survival time. $P$ $<0.05$ was considered statistically significant. Spearman bivariate correlation analysis was used to determine the correlation between herbs and survival time. $P<0.01$ was considered statistically significant. Statistical analyses were performed by using SPSS 19.0.

\section{Abbreviations}

BC: breast cancer; Bcl-2: B-cell lymphoma-2; CA153: carbohydrate antigen-153; CDK1: cyclin-dependent kinases1; CEA: carcino-embryonic antigen; CHM: Chinese Herbal Medicine; cI-cT: candidate ingredienttarget; CR: Citri Reticulatae Folium; DL: drug-likeness; DNA: deoxyribonucleic acid; EGFR: epidermal growth factor receptor; EH: Epimedium Herb; ER: estrogen receptor; PR: progesterone receptor; ERE: estrogen response element; ET: endocrine treatment; FTB: Fritillariae Thunbergii Bulbus; GC: Ginger Charcoal; Her2: human epidermalgrowth factor receptor-2; HIT: Herbal Ingredients' Targets; HSP90: heat shock protein90; HR: hazard ratio; IL-6: interleukin- 6; IL-1 $\beta$ : interleukin1 $\beta$; KM: Trichosanthes Kirilowii Maxim; Lic: Licorice; MAPK: mitogen-activated protein kinase; MBC: Metastatic breast cancer; NT: Cervus Nippon Temminck; OS: Overall Survival; PN: Panax Notoginseng; PR: Phytolaccae Radix; RP: Citri Reticulatae Pericarpium Viride; Scr: Sarcoma; TCMID: Traditional Chinese Medicine Integrative Database; TCMSP: Traditional Chinese Medicine Systems Pharmacology; TNF- $\alpha$ : Tumor Necrosis Factor; TOP-II: Topoisomerase II; TTD: Therapeutic Target Database; VEGF: vascular endothelial growth factor; VEGFR: vascular endothelial growth factor receptor; WM: western medicine; AP-1 :activator protein 1.

\section{Authors' contributions}

Yu Mao, Jian Hao: study concept and design; acquisition of data; analysis and interpretation of data; drafting of the manuscript; critical revision of the manuscript for important intellectual content; statistical analysis; Zi-qi Jin, Yang-yang Niu, Xue Yang, Dan Liu, Cui-hong Zhu, Rui Cao: acquisition of data; analysis and interpretation of data; Xiong-zhi Wu: study concept and design; critical revision of the manuscript for important intellectual content; obtained funding; administrative, 
technical, or material support; study supervision all authors reviewed the manuscript.

\section{ACKNOWLEDGMENTS}

This study was supported under the National Science Foundation of China (No. 81473441).

\section{CONFLICTS OF INTEREST}

The authors declared no potential conflicts of interest with respect to the research, authorship and/or publication of this article.

\section{REFERENCES}

1. Torre LA, Bray F, Siegel RL, Ferlay J, Lortet-Tieulent J, Jemal A. Global cancer statistics, 2012. CA Cancer J Clin. 2015; 65:87-108.

2. Siegel RL, Miller KD, Jemal A. Cancer statistics, 2016. CA Cancer J Clin. 2016; 66: 7-30.

3. Torre LA, Siegel RL, Ward EM, Jemal A. Global cancer incidence and mortality rates and trends - an update. Cancer Epidemiology Biomarkers \& Prevention. 2016; 25: 16-27.

4. Chen W, Zheng R, Baade PD, Zhang S, Zeng H, Bray F, Jemal A, Yu XQ, He J. Cancer statistics in China, 2015. CA Cancer J Clin. 2016; 66: 115-132.

5. DeSantis C, Ma J, Bryan L, Jemal A. Breast cancer statistics, 2013. CA Cancer J Clin. 2014; 64:52-62.

6. Raphael J, Verma S. Overall survival (OS) endpoint: an incomplete evaluation of metastatic breast cancer (MBC) treatment outcome. Breast cancer research and treatment. 2015; 150: 473-478.

7. Gennari A, Conte PF, Rosso R, Orlandini C, Bruzzi P. Survival of metastatic breast carcinoma patients over a 20-year period. Cancer. 2005; 104: 1742-1750.

8. Di Meglio A, Freedman RA, Lin NU, Barry WT, MetzgerFilho O, Keating NL, King TA, Sertoli MR, Boccardo F, Winer EP, Vaz-Luis I. Time trends in incidence rates and survival of newly diagnosed stage IV breast cancer by tumor histology: a population-based analysis. Breast cancer research and treatment. 2016; 1-10.

9. Qi F, Zhao L, Zhou A, Zhang B, Li A, Wang Z, Han J. The advantages of using traditional Chinese medicine as an adjunctive therapy in the whole course of cancer treatment instead of only terminal stage of cancer. Bioscience trends. 2015; 9: 16-34.

10. Li X, Yang G, Li X, Zhang Y, Yang J, Chang J, Sun X, Zhou X, Guo Y, Xu Y, Liu J, Bensoussan A. Traditional Chinese medicine in cancer care: a review of controlled clinical studies published in Chinese. PloS one. 2013; 8: e60338.

11. Yang X, Hao J, Zhu CH, Niu YY, Ding XL, Liu C, Wu XZ. Survival benefits of Western and traditional Chinese medicine treatment for patients with pancreatic cancer. Medicine. 2015; 94.

12. Hsu RJ, Hsu YC, Chen SP, Fu CL, Yu JC, Chang FW, Chen YH, Liu JM, Ho JY, Yu CP. The triterpenoids of Hibiscus syriacus induce apoptosis and inhibit cell migration in breast cancer cells. BMC complementary and alternative medicine. 2015; 15: 1 .

13. Iwanowycz S, Wang J, Hodge J, Wang Y, Yu F, Fan D. Emodin inhibits breast cancer growth by blocking the tumor-promoting feedforward loop between cancer cells and macrophages. Molecular cancer therapeutics. 2016; molcanther. 0987.

14. Tan XL, Guo L, Wang GH. Polyporus umbellatus inhibited tumor cell proliferation and promoted tumor cell apoptosis by down-regulating AKT in breast cancer. Biomedicine \& Pharmacotherapy. 2016; 83: 526-535.

15. Wu CT, Lai JN, Tsai YT. The prescription pattern of Chinese herbal products that contain dang-qui and risk of endometrial cancer among tamoxifen-treated female breast cancer survivors in Taiwan: a population-based study. PloS one. 2014; 9: e113887.

16. Hopkins AL. Network pharmacology: the next paradigm in drug discovery. Nature chemical biology. 2008; 4: 682-690.

17. Poornima P, Kumar JD, Zhao Q, Blunder M, Efferth T. Network pharmacology of cancer: From understanding of complex interactomes to the design of multi-target specific therapeutics from nature. Pharmacological Research. 2016; 111: 290-302.

18. Yang H, Qin C, Li YH, Tao L, Zhou J, Yu CY, Xu F, Chen Z, Zhu F, Chen YZ. Therapeutic target database update 2016: enriched resource for bench to clinical drug target and targeted pathway information. Nucleic Acids Res. 2016; 44:1069-74.

19. Bosch A, Eroles P, Zaragoza R, Viña JR, Lluch A. Triplenegative breast cancer: molecular features, pathogenesis, treatment and current lines of research. Cancer treatment reviews. 2010; 36: 206-215.

20. Calza S, Hall P, Auer G, Bjöhle J, Klaar S, Kronenwett U, Liu ET, Miller L, Ploner A, Smeds J, Bergh J, Pawitan Y. Intrinsic molecular signature of breast cancer in a population-based cohort of 412 patients. Breast Cancer Research. 2006; 8: 1.

21. Perou CM, Sørlie T, Eisen MB, van de Rijn M, Jeffrey SS, Rees CA, Pollack JR, Ross DT, Johnsen H, Akslen LA, Fluge O, Pergamenschikov A, Williams C, et al. Molecular portraits of human breast tumours. Nature. 2000; 406: 747-752.

22. Davis AP, Grondin CJ, Lennon-Hopkins K, SaraceniRichards C, Sciaky D, King BL, Wiegers TC, Mattingly CJ. The Comparative Toxicogenomics Database's 10th year anniversary: update 2015. Nucleic Acids Res. 2015; 43: D914-20.

23. Gao L, Wang XD, Niu YY, Duan DD, Yang X, Hao J, Zhu CH, Chen D, Wang KX, Qin XM, Wu XZ. Molecular 
targets of Chinese herbs: a clinical study of hepatoma based on network pharmacology. Scientific reports. 2016; 6 .

24. Ru J, Li P, Wang J, Zhou W, Li B, Huang C, Li P, Guo Z, Tao W, Yang Y, Xu X, Li Y, Wang Y et al. TCMSP: a database of systems pharmacology for drug discovery from herbal medicines. Journal of cheminformatics. 2014; 6: 1.

25. Xue R, Fang Z, Zhang M, Yi Z, Wen C, Shi T. TCMID: traditional Chinese medicine integrative database for herb molecular mechanism analysis. Nucleic acids research. 2012; gks1100.

26. Ye H, Ye L, Kang H, Zhang D, Tao L, Tang K, Liu X, Zhu R, Liu Q, Chen YZ, Li Y, Cao Z. HIT: linking herbal active ingredients to targets. Nucleic Acids Res. 2011; 39: D1055-D1059.

27. Gong J, Cai C, Liu X, Ku X, Jiang H, Gao D, Li H. ChemMapper: a versatile web server for exploring pharmacology and chemical structure association based on molecular 3D similarity method. Bioinformatics. 2013; 29:1827-1829.

28. Smoot ME, Ono K, Ruscheinski J, Wang PL, Ideker T. Cytoscape 2.8: new features for data integration and network visualization. Bioinformatics. 2011; 27: 431-432.

29. Scardoni G, Petterlini M, Laudanna C. Analyzing biological network parameters with CentiScaPe. Bioinformatics. 2009; 25: 2857-2859.

30. Li J, Lu C, Jiang M, Niu X, Guo H, Li L, Bian Z, Lin $\mathrm{N}, \mathrm{Lu}$ A. Traditional chinese medicine-based network pharmacology could lead to new multicompound drug discovery. Evidence-Based Complementary and Alternative Medicine. 2012; 2012.

31. Zhang B, Wang X, Li S. An integrative platform of TCM network pharmacology and its application on a herbal formula, Qing-Luo-Yin. Evidence-Based Complementary and Alternative Medicine. 2013; 2013.

32. Sant M, Allemani C, Berrino F, Coleman MP, Aareleid T, Chaplain G, Coebergh JW, Colonna M, Crosignani P, Danzon A, Federico M, Gafà L, Grosclaude P, et al. Breast carcinoma survival in Europe and the United States. Cancer. 2004; 100: 715-722.

33. Zeichner SB, Herna S, Mani A, Ambros T, Montero AJ, Mahtani RL, Ahn ER, Vogel CL. Survival of patients with de-novo metastatic breast cancer: analysis of data from a large breast cancer-specific private practice, a universitybased cancer center and review of the literature. Breast Cancer Research and Treatment. 2015; 153: 617-624.

34. Slamon DJ, Leyland-Jones B, Shak S, Fuchs H, Paton V, Bajamonde A, Fleming T, Eiermann W, Wolter J, Pegram M, Baselga J, Norton L. Use of chemotherapy plus a monoclonal antibody against HER2 for metastatic breast cancer that overexpresses HER2. New England Journal of Medicine. 2001; 344: 783-792.

35. Kawano A, Shimizu C, Hashimoto K, Kinoshita T, Tsuda H, Fujii H, Fujiwara Y. Prognostic factors for stage IV hormone receptor-positive primary metastatic breast cancer. Breast Cancer. 2013; 20: 145-151.

36. Tevaarwerk AJ, Gray RJ, Schneider BP, Smith ML, Wagner LI, Fetting JH, Davidson N, Goldstein LJ, Miller KD, Sparano JA. Survival in patients with metastatic recurrent breast cancer after adjuvant chemotherapy. Cancer. 2013; 119: 1140-1148.

37. Lee YW, Chen TL, Shih YR, Tsai CL, Chang CC, Liang $\mathrm{HH}$, Tseng SH, Chien SC, Wang CC. Adjunctive traditional Chinese medicine therapy improves survival in patients with advanced breast cancer: A population-based study. Cancer. 2014; 120: 1338-1344.

38. Li Y, Zhu X, Bensussan A, Li P, Moylan E, Delaney G, McPherson L. Herbal Medicine for Hot Flushes Induced by Endocrine Therapy in Women with Breast Cancer: A Systematic Review and Meta-Analysis. Evid Based Complement Alternat Med, 2016. 2016; p. 1327251.

39. Romagnolo DF, Selmin OI. Flavonoids and cancer prevention: a review of the evidence. J Nutr Gerontol Geriatr. 2012;31, 206-238.

40. Tomé-Carneiro J, Larrosa M, González-Sarrías A, Tomás-Barberán FA, García-Conesa MT, Espín JC. Resveratrol and clinical trials: the crossroad from in vitro studies to human evidence. Curr Pharm Des. 2013; 19, 6064-6093.

41. Pan H, Zhou W, He W, Liu X, Ding Q, Ling L, Zha X, Wang S. Genistein inhibits MDA-MB-231 triple-negative breast cancer cell growth by inhibiting NF- $\mathrm{B}$ activity via the Notch-1 pathway. Int. J. Mol.Med. 2012; 30, 337-343.

42. Park CH, Chang JY, Hahm ER, Park S, Kim HK, Yang CH. Quercetin, a potent inhibitor against $\beta$-catenin/Tcf signaling in SW480 colon cancer cells. Biochem Bioph Res Co. 2005; 328: 227-234.

43. Jeong J H, An J Y, Kwon Y T, Rhee J G, Lee Y J. Effects of low dose quercetin: Cancer cell-specific inhibition of cell cycle progression. J Cell Biochem. 2009; 106: 73-82.

44. Murakami A, Ashida H, Terao J. Multitargeted cancer prevention by quercetin. Cancer let. 2008; 269: 315-325.

45. Ferry DR, Smith A, Malkhandi J, Fyfe DW, deTakats PG, Anderson D, Baker J, Kerr DJ. PhaseI clinical trial of the flavonoid quercetin: pharmacokinetics and evidence for in vivo tyrosine kinase inhibition. Clin Cancer Res. 1996; 2 : 659-668.

46. Yoshida M, Sakai T, Hosokawa N, Marui N, Matsumoto K, Fujioka A, Nishino H, Aoike A. The effect of quercetin on cell cycle progression and growth of human gastric cancer cells. FEBS let.1990; 26:10-13.

47. Chien SY, Wu YC, Chung JG, Yang JS, Lu HF, Tsou MF, Wood WG, Kuo SJ, Chen DR. Quercetin-induced apoptosis acts through mitochondrial-and caspase-3-dependent pathways in human breast cancer MDA-MB-231 cells. Human \& experimental toxicology. 2009; 28: 493-503.

48. Choi EJ, Bae SM, Ahn WS. Antiproliferative effects of quercetin through cell cycle arrest and apoptosis in human 
breast cancer MDA-MB-453 cells. Archives of pharmacal research. 2008; 31: 1281-1285.

49. Choi EJ, Ahn W S. Kaempferol induced the apoptosis via cell cycle arrest in human breast cancer MDA-MB-453 cells. Nutrition research and practice. 2008; 2: 322-325.

50. Miean KH, Mohamed S. Flavonoid (myricetin, quercetin, kaempferol, luteolin, and apigenin) content of edible tropical plants. Journal of agricultural and food chemistry. 2001; 49: 3106-3112.

51. Wang Z Y, Nixon D W. Licorice and cancer. Nutrition and cancer. 2001; 39: 1-11.

52. Tamir S, Eizenberg M, Somjen D, Stern N, Shelach R, Kaye A, Vaya J. Estrogenic and antiproliferative properties of glabridin from licorice in human breast cancer cells. Cancer research. 2000; 60: 5704-5709.

53. Xiao HH, Fung CY, Mok SK, Wong KC, Ho MX, Wang XL, Yao XS, Wong MS. Flavonoids from Herba epimedii selectively activate estrogen receptor alpha $(\mathrm{ER} \alpha)$ and stimulate ER-dependent osteoblastic functions in UMR106 cells. J Steroid Biochem Mol Biol. 2014; 143: 141-151.

54. Yap SP, Shen P, Li J, Lee LS, Yong EL. Molecular and pharmacodynamic properties of estrogenic extracts from the traditional Chinese medicinal herb, Epimedium. Journal of ethnopharmacology. 2007; 113: 218-224.

55. Yong EL, Wong SP, Shen P, Gong YH, Li J, Hong Y. Standardization and evaluation of botanical mixtures: lessons from a traditional Chinese herb, Epimedium, with oestrogenic properties. Novartis Found Symp. 2007; 282: 173-188.

56. Bauer KR, Brown M, Cress RD, Parise CA, Caggiano V. Descriptive analysis of estrogen receptor (ER)-negative, progesterone receptor ( $\mathrm{PR}$ )-negative, and HER2-negative invasive breast cancer, the so-called triple-negative phenotype. Cancer. 2007; 109: 1721-1728.

57. Miyoshi Y, Murase K, Saito M, Imamura M, Oh K. Mechanisms of estrogen receptor- $\alpha$ upregulation in breast cancers. Medical molecular morphology. 2010; 43: 193-196.

58. Clemons M, Goss P. Estrogen and the risk of breast cancer. New England Journal of Medicine. 2001; 344: 276-285.

59. Damianaki A, Bakogeorgou E, Kampa M, Notas G, Hatzoglou A, Panagiotou S, Gemetzi C, Kouroumalis E, Martin PM, Castanas E. Potent inhibitory action of red wine polyphenols on humanbreast cancer cells. J Cell Biochem 2000; 78: 429-441.

60. Maggiolini M, Bonofiglio D, Marsico S, Panno ML, Cenni B, Picard D, Andò S. Estrogen receptor $\alpha$ mediates the proliferative but not the cytotoxic dose-dependent effects of two major phytoestrogens on human breast cancer cells. Mol Pharmacol. 2001; 60: 595-602.

61. Bowers JL, Tyulmenkov VV, Jernigan SC, Klinge CM. Resveratrol acts as a mixed agonist/antagonist for estrogen receptors $\alpha$ and $\beta$. Endocrinology. 2000; 141: 3657-3667.

62. Beliakoff J, Whitesell L. Hsp90: an emerging target for breast cancer therapy. Anti-cancer drugs. 2004; 15: 651-662.

63. Pratt WB. The hsp90-based chaperone system: involvement in signal transduction from a variety of hormone and growth factor receptors. Proc Soc Exp Biol Med. 1998; 217: 420-434.

64. Pick E, Kluger Y, Giltnane JM, Moeder C, Camp RL, Rimm DL, Kluger HM. High HSP90 expression is associated with decreased survival in breast cancer. Cancer Res. 2007; 67: 2932-2937.

65. Järvinen TA, Tanner M, Bärlund M, Borg A, Isola J. Characterization of topoisomerase II alpha gene amplification and deletion in breast cancer. Genes Chromosomes Cancer. 1999; 26: 142-50.

66. Lynch BJ, Guinee DG, Holden JA. Human DNA topoisomerase II-alpha: a new marker of cell proliferation in invasive breast cancer. Human pathology. 1997; 28: $1180-1188$. 